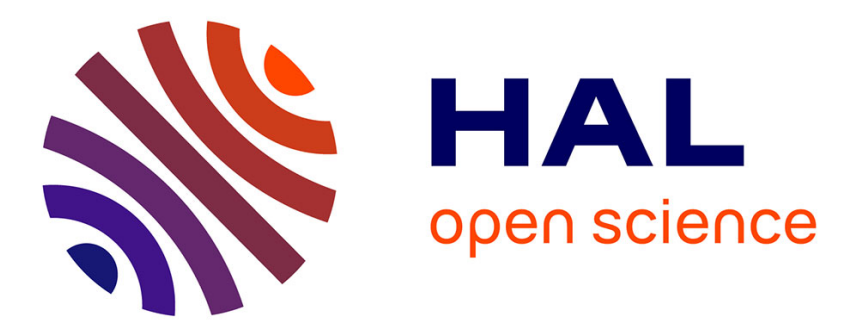

\title{
Meningococcal vaccines: current state and future outlook
}

\author{
Marion Leca, Charléric Bornet, Marc Montana, Christophe Curti, Patrice \\ Patrice Vanelle
}

\section{- To cite this version:}

Marion Leca, Charléric Bornet, Marc Montana, Christophe Curti, Patrice Patrice Vanelle. Meningococcal vaccines: current state and future outlook. Pathologie Biologie, 2015, 63 (3), pp.144-151. hal-01425358

\section{HAL Id: hal-01425358 \\ https://hal.science/hal-01425358}

Submitted on 3 Jan 2017

HAL is a multi-disciplinary open access archive for the deposit and dissemination of scientific research documents, whether they are published or not. The documents may come from teaching and research institutions in France or abroad, or from public or private research centers.
L'archive ouverte pluridisciplinaire HAL, est destinée au dépôt et à la diffusion de documents scientifiques de niveau recherche, publiés ou non, émanant des établissements d'enseignement et de recherche français ou étrangers, des laboratoires publics ou privés. 


\section{Les vaccins méningocciques : état des lieux et perspectives}

\section{Meningococcal vaccines: current state and future outlook}

Leca Marion, ${ }^{1}$ Bornet Charléric, ${ }^{2}$ Montana Marc, ${ }^{3,4}$ Curti Christophe, ${ }^{4,5}$ Vanelle Patrice. ${ }^{4,5}$

1. Assistance Publique - Hôpitaux de Marseille (AP-HM), Pharmacie Usage Intérieur Hôpital Nord, Marseille, France

2. Assistance Publique - Hôpitaux de Marseille (AP-HM), Pharmacie Usage Intérieur Hôpital de la Conception, Marseille, France

3. Assistance Publique - Hôpitaux de Marseille (AP-HM), Oncopharma, Marseille, France

4. Aix-Marseille Université, CNRS, Institut de Chimie Radicalaire ICR, UMR 7273, Laboratoire de PharmacoChimie Radicalaire, Marseille, France

5. Assistance Publique - Hôpitaux de Marseille (AP-HM), Service Central de la Qualité et de l'Information Pharmaceutiques (SCQIP), Marseille, France

Correspondence and offprints:Patrice Vanelle,Aix-Marseille Université, UMR CNRS 7273, Laboratoire de Pharmaco-Chimie Radicalaire, faculté de pharmacie, 27 boulevard Jean Moulin, 13385 Marseille, cedex 05, France. patrice.vanelle@univ-amu.fr Tel.: +33-4-9183-5580; Fax: +33-4-9179-4677. 
Résumé

\section{Abstract}

Neisseria meningitidis infections are a major public health problem worldwide.Although conventional approacheshave not led to development of a serogroup B meningococcal vaccine, a new technique based on genome sequencing has created new perspectives. Recently, a universal serogroup B meningococcal vaccine, Bexsero ${ }^{\circledR}$, was licensed in Europe, Australiaand United States, following several clinical studies demonstrating its immunogenicity and safety. Availability of this vaccine could contribute positively to human health, by significantly reducing the incidence of meningococcal infections. However, unfavorable cost-effectiveness analysis means that routine vaccination is not currently recommended. Another serogroup meningococcal vaccine, Trumemba ${ }^{\circledR}$, was also recently licensed in United States.Like any drug, Bexsero ${ }^{\circledR}$ and Trumemba ${ }^{\circledR}$ will require close observation to assesstheir impact on meningococcal epidemiology.

Keywords:Neisseria meningitidis, vaccine, Bexsero ${ }^{\circledR}$, Trumemba ${ }^{\circledR}$ reverse vaccinology 
Invasivemeningococcal disease(IMD) is perceived as a serious threat by the public, who are veryinfluencedboth by the media,andbythe medical professions.[1]These infectionshavedifferentclinical

consequences(meningitis,septicemia, arthritis,pneumonia, andpericarditis), which canoccur simultaneously, sometimes inducing misdiagnosis.[2,3]

Meningococcal infectionsremaina public healthproblem throughout the world.[2,4]Indeed, in the context of the developmentand accessibility ofrelatively newvaccines(especiallyagainstHaemophilusinfluenzae

typebandStreptococcus pneumoniae), Neisseria meningitidisis considered one ofthemost frequentinfectious causesof deathoutside the neonatal period.[5-7]The diversity ofmeningococcal strainsis correlated tothe antigenic variabilityof the bacterialcapsule.[8,9]

In accordance withserologicalmethods based onthe composition of the polysaccharide capsule, an international nomenclaturewas established toidentify andto monitorprecisely

epidemicclones.[10]ThisclassifiesNeisseriainto13distinct serogroups, of which6 (A,B, C, W135, $\mathrm{X}$ andY) are distinguished by their highvirulencefor humans.[3,8,9,11]

Since theintroductionof polysaccharide conjugate vaccinesagainstserogroupsA, C, W-135 andY, serogroup Bhas emerged asthe basic cause ofIMD, particularly in Europe and NorthAmerica,where itcreates hyperendemic or epidemic situations, especially due to the lack of prophylaxis for this serogroup. $[4,11]$

Thus, the best strategyagainstIMDremainsprimary preventionviameningococcalvaccination, including the development of avaccine targetingserogroup B.[3,10,12,13]

\section{Development of a meningococcalgroup B vaccine}

\subsection{The needfor meningococcalgroup B vaccine}

The epidemiology ofmeningococcal diseaseis dynamic: allserogroupsvarytemporallyand geographically.[6,10,14] Thismarked disparitycan mainly be explainedby differencesin immunity among ethnic groups,andby the influence of environmental factors.[3,6]

Each year, IMD estimatesrise by1.2 million casesworldwide, including 135,000 deaths.[12]In response to thesealarming statistics, the World Health Organization(WHO)has for example introducedspecificvaccinationcampaignsagainst serogroupAin Africa where it is predominantto limitlargemeningococcalepidemics.[14,15]

However, the threat persists, especially in industrialized countries where serogroup B is involved in most cases of IMD (84\% of IMD in Australia, 83\% in New Zealand, $76 \%$ in Europe and $35 \%$ in the United States).In Europe, the annual incidence of serogroup B is 1 case per 100,000 population.[14]

According to epidemiology data, some populations are more sensitive to infection. In the United States, nearly $60 \%$ of IMD in infants under the age of 59 months is caused by serogroup B.[16]

In France,the highestincidenceis observedin infantsaged 0-12 months, withthe annual incidencereaching 11.1cases per 100,000 population. This rateis correlated to the immaturity of their immune system.

Ahigh incidence is also observedlater,in young adultsaged 15-24: at 19years, the incidencerisesto 2.89 cases per 100,000 population.[17,18]The social behavior ofyoung adults 
canfacilitateexposureto strainsagainstwhich theyhave no immunity.[17,19]

IMDs are characterized by theirglobal distribution, theirepidemic potential, their unpredictability(theirpotential toalterthe health ofa healthy individualwithoutany history of illness), theirrapidprogressionand theirminor andnonspecificsymptoms.[3,6,8,20,21]All thesefactorsexplainthe severity of theseinfections, andwhy rapiddiagnosisand immediateinitiation of treatment are vital.[2]

Despite technicalandtherapeutic advances, the overall mortality rate remains between $10 \%$ and $15 \%$, and up to $19 \%$ ofsurvivors have disablingsequelaesuch ashearing loss, cognitive dysfunction, motor nerve deficits, seizure disorders, amputation.[16,20]

Given the severity of meningococcalinfections, developing ameningococcalBvaccinethat can controlthe most of thesedevastating epidemicshas become a realpriority formedical research.[17,22]

\subsection{Special features of serogroup B}

Meningococcal vaccines targeting serogroups A, C, W-135 and $\mathrm{Y}$ have demonstrated their effectiveness.[6,23] However, there are a number of reasons why the immunological approach to traditional vaccine development, conjugate or polysaccharide, isout of the question for serogroup B.[6,13,24,25]

First, the heterogeneity of intra-serogroup proteins, especially the dominant protein, Porin A (PorA), seriously complicates universal vaccine design.[26,27]

Up to now, only specific vaccines prepared from vesicles on the bacterium surface, outer membrane vesicle (OMV), were developed and used as the need arose. They were used fordisease control in epidemic situations in Brazil, Chile, Cuba (VaMencog-BC®), Norway (MenBVac® vaccine), New Zealand (MenZB ${ }^{\circledR}$ vaccine) and recently in France (Norwegian MenBVac® vaccine because of epidemic strain similarity).[4,22,28-35]The composition of these vaccines was determined by a particular bacterial clonal strain, so their effectiveness waslimited to certain epidemic conditions.[24,27] For example, the Cuban vaccine, which showed an effectivenessrate of about $83 \%$ in Cuban children aged above 4, wasless effective in Brazilian children,with an effectiveness rate of $74 \% .[28,31,36]$ Moreover, Cuban vaccine effectiveness in Brazilian newborns appeared to be considerably lower than that reported for Cuba newborns.[28] These vaccines, termed tailor-made, are poorly immunogenic in children less than 4 years old, and the duration of protection is limited.[4,10,37] These protein vaccines do not therefore constitute a global vaccination strategy against serogroup B.[25,28,38]

Secondly, the polysaccharide capsule of serogroup B contains polysialic acid, as do all the capsules of meningococcal virulent serogroups, with the exception of serogroup A which is composed mainly of $\mathrm{N}$ acetylmannosamine-1-phosphate.[3] The main difference between serogroups $\mathrm{B}$ and $\mathrm{C}$ is their linkage patterns: the group B capsule has 2-8 linkagewhile group C has2-9 linkage.[38]

The final structure is sufficiently different to induce specific antibodies for each serogroup.[6] The derivative of the polysialic acid contained in the serogroup B capsule is found in many human tissues, especially in the central nervous system, and particularlyinadhesion cells (Neural cell Adhesion Molecule N-CAM), highly expressed inthe fetus 
and the young child in development.[26,39,40] Crossreactivity between $\mathrm{N}-\mathrm{CAM}$ embryonic isoforms and sera from patients with serogroup $\mathrm{B}$ meningococcuswas also demonstrated while this reactionwas absent in healthy subjects.[39] Molecular mimicry induces low immunogenicity, attributed to immunological tolerance by the host to the sialylatedglycopeptides, physiologically containedin some body zones.[25]Consequently, if this antigen was included in a vaccine, T-cells, particularly $\mathrm{T}$ lymphocytes, might recognizetheselfantigen.[25,39]Antibodies secreted by the immune system would be directed against a molecule physiologically present in the human body, and might causeautoimmune disorders, particularly in the brain.Despite various attempts, particularly chemical modification of the $\mathrm{N}$-acetyl group, there has been no real success.[41]

The real challenge is therefore to develop a multivalent vaccine to expand vaccine coverage and to avoid the risk of selecting for vaccine escape variants against a pathogen that mimics host molecules.[27]

\subsection{Reverse vaccinology, an innovative and}

\section{promising technique}

The conventional approach to vaccine development proceeds via the in vitroculture of the pathogenic organism, allowing potential antigenic components to be individually identified by biochemical, immunological and microbiological methods.[37,42]Finally, each isolated antigen is analyzed to determine its ability to induce protective immunity. Although this long and tedious technique, termed "classical vaccinology", has led tomany vaccines commonly used today, it still presents some limitations.[42]It cannotbe applied to all micro-organisms, excluding all bacteria difficult to cultivate or non-cultivableand also antigenically variant, especially meningococcal serogroup B. Moreover, antigens expressed only during in vivo infection are not produced under laboratory conditions and therefore not analyzed.[42]

Scientists have recently proposed a new concept, called "reverse vaccin7logy".[39]This new strategy is based on the complete sequencing of the bacterial genome, to identify potential, highly immunogenicantigens, regardless of their expression level.[37,42-45]This technique presents the advantage of applying to all germs, pathogenic or commensal, cultivable or not. However, it does not detect non-protein antigens such as capsular polysaccharides and glycolipids, whichnevertheless remain promising as components for future vaccines.[44]Reverse vaccinology was applied for the first time in 2000 , on a virulent strain of meningococcal group B (MC58).[45,46] The entire sequence of the bacterial genome wasanalyzed:nearly 600 candidate genes encoding for new surface-exposed proteins were identified.[42,44] The predicted proteins were cloned and expressed in Escherichia coli.[37,42,44,46]

Of these, 350 putative surface proteinswere successfully expressed, purified and then tested on mice. The sera were analyzed, in particular by Western Blot to confirm the expression of these proteins in vivo.Furthermore, enzymelinked immunosorbent assay(ELISA) and fluorescenceactivated cell sorting(FACS) were used to determine the exact location of these proteins and their function. [37,42,4446] Protein antigens selected were classified according to their serum bactericidal activity (SBA) against the target strain.Among the 91 proteins inducing bactericidal antibodies in animals, about 25 , not detected by conventional 
techniques, were selected for their surface location.[42,45,46]Moreover, these antigens were recognized by the serum of patients who haddeveloped meningococcal disease. Finally, only 3 protein antigens were selected for their characteristic properties, allowing thedevelopment of the recombinant protein (rMenB). This was the first example of real success, resulting in a universal vaccine againstmeningococcal group B.[37,44]The new strategywas then applied to the development of vaccines against other pathogens, such as Streptococcus agalactiae, Streptococcus pyogenes, Streptococcus pneumoniae, Chlamydia pneumoniae ...[37,46,47]

\section{The marketing of the first universal meningococcal serogroup B vaccine}

\subsection{The formulation of the new vaccine}

To ensure that protection is the most universal possible and to avoid the emergence of mutants, the ideal solution is to developa multi-antigenic meningococcal vaccine.[27,45,48] Reverse vaccinology yielded 3 vaccine antigens, commonly called Neisseria genome-derived antigens (GNA).[44,45]

- Factor H binding protein (fHBP), also named GNA 1870 or rLP 2086 fused to GNA 2091: A surface-exposed lipoprotein expressed by most strains of meningococcal group B, itsexpression is highly variable.[6,27,45,49,50] Meningococcal B vaccine includes the sub-variant 1 or the subgroup B, which is the most common. Secreted antibodies are specific and exclusively protect the host against strains presenting this variant.For the development of a universal vaccine, it is therefore advisable to add at least one other antigen, to expand coverage.[49] This fHbp protein is implicated in the regulation of the alternative complement pathway essential for bacterial lysis.[6,45] Blocking this protein through a vaccine, would help the host's immune system to clear the bacteria from the body.

- Neisseria adhesinA (NadA) or GNA 1994: This protein is present in only $50 \%$ of the tested strains, but is found in most clonal hypervirulent serogroup B strains in Europe.[46,5153] In contrast to the 2 other principal antigens of the vaccine, this trimeric protein is not associated with an accessory protein.[24,45,53] This protein allows host cell adhesion and invasion, so it would have an indispensable function in asymptomatic carriers.[51,53] The induced antibodies should have the potential to stop bacterial colonization and thus to prevent invasive disease, but this hypothesis was not confirmed by scientific evidence.[27]In contrast, the secretion of protective antibodies in laboratory animals was proven, and the sera of patients who reported a meningococcal disease recognize the protein: this shows that NadAplays a major role not only in the virulence of meningococci but also in immunogenicity in humans.[27,51,52]

- Neisseria Heparin Binding Antigen (NHBA) or GNA 2132, fused to GNA1030: This is a ubiquitous lipoprotein which is specific for Neisseria species with a variety of proteins.[50] In mice, antibodies developed showed bactericidal activity mediated by the complement, and the sera of patients with a history of meningococcal disease also recognize the protein.[45,54]

The 2 accessory proteins, GNA 2091 and GNA 1030, respectively fused tofHbp and NHBA, reinforce the immune responses and enhance the stability of the final recombinant protein.[27,45] An outer membrane vesicle (OMV)derived from a serogroup B New Zealand strain (strain NZ98 / 254) 
is firstly added to these 3principal proteins in order to enhance immunogenicity, followed by an adjuvant, aluminum hydroxide, currently controversial.[55-58]

This is the formulationof the new multicomponent vaccine 4CMenB (for 4 components against meningococcus B) recently marketed under the name Bexsero $^{\circledR}$.It obtainedmarketing authorization in Europe in January 2013 as the first broad spectrum vaccine for Neisseria meningitidis

serogroup B.[6,12,38] In August 2013, this vaccine was also approved in Australia,[12] and in January 2015 in United States.[59]

In October 2014, another serogroup meningococcal vaccine, Trumemba $^{\circledR}$, was licensed in United States. This vaccine consists of two fHBP variants immunologically distincts (A05 and B01).[60]Although clinical trials for this second vaccine were conducted in the United States, Australia but also in Europe, Trumemba ${ }^{\circledR}$ is not yet licensed in Europe.

\section{2. The effectiveness of $4 \mathrm{CMenB}$}

The relatively low incidence of IMD ruled out performingefficacy studies of the new vaccine prior to marketing authorization. Thus, $4 \mathrm{CMenB}$ was basically awarded marketing authorization on evidence of immunogenicity and safety data rather than on a formal demonstration of its effectiveness.[4,13,61] To estimate the effectiveness of a new vaccine, immunogenicity and immunization coverage must be taken into account, and there are standardized analytical methods for a true consensus.[6,23]Goldschneiderdemonstrated in 1969 the inverse correlation between the incidence of a disease and the presence of bactericidal antibodies in human sera, meaning that the probability of contracting the disease depends on the amount of circulating antibodies.[23,62] Further to these observations, circulating bactericidal antibodies were accepted as true markers of protection against IMD.[61,62]The SBA assay is considered the most relevant immunological indicator, the one most closely correlated with clinical efficacy.[61,63,64] This test consists in introducing a viable Neisseria meningitidis suspension in different serum dilutions in the presence of a human complement (hSBA) and then determining the amount of surviving bacteria.[63] The dilution at which more than $50 \%$ of bacteria are immediately killed was for the 3 vaccine antigens: fHbp, NadA and PorA[6,23,35]. This assay could not be performed for NHBA protein, which was analyzed by ELISA.[65] An SBA titer of $\geq 1: 4$ is considered a surrogate of protection,although some clinical trials in infants have set the threshold at 5 , to be on the safe side.[66,67] However, this technique requires many SBA assays for various endemic strains for each geographic region;in practice, this is impossible, especially with respect to infants, whose serum volumes are very limited.[56,68]

Because of the diversity of intra-serogroup antigens, a standardized method specific to the $4 \mathrm{CMenB}$ vaccine, the Meningococcal Antigenic Typing System(MATS) was developed to estimate vaccination coverage. MATS indicates the probability that the analyzed meningococcal strain will be killed by the serum of an immunized patient.This method allows the characterization and quantification, viaimmuneenzymatic ELISA analysis, of the concentration of each vaccine antigen.[13,68] Then it compares the expression obtained from theanalyzed strain with standard rates from reference strains.[68,69] This comparison determines the relative potency (RP) essential to definethe positive 
bactericidal threshold (PBT). PBT represents the minimum level of expression of each vaccine antigen to ensure sufficient bactericidal activity.[68-70] The objective is to estimate the percentage of circulating strains with a satisfactory PBT, equivalent toimmunization coverage. The presence of the gene encoding the protein PorA is detected by PCR, and the sub-type is determined by sequencing.[68] A strain is considered sensitive to $4 \mathrm{CMenB}$ vaccine if it expresses the P1.4 subtype of PorA protein or if 1 of the 3 antigens has a sufficient level of expression.[70] Studies have shown that if a strain exceeds the positive threshold for only 1 of the 3 vaccine antigens, the probability of being killed by the host antibodies is $80 \%$. On the other hand, if a strain exceeds the positive threshold for at least 2 vaccine antigens, the probability of being killed by the antibodies is 96\%.[68]The MATS test, individually evaluating vaccine antigens, neglects potential synergy for strains expressing more protein antigens and underestimates immunization coverage.[70,71]

The $4 \mathrm{CMenB}$ vaccine would cover $66 \%$ of the pathogenic strains in Canada, $76 \%$ in Australia, $78 \%$ in Europe, $85 \%$ in France and Norway.[69,70,72,73] Data from clinical trials on 4 CMenB vaccine prove its immunogenicity in infants, adolescents and adults.[48,65] In infants, whatever the vaccination schedule (primary vaccination at 2, 4, and 6 months or 2,3 and 4 months), more than $99 \%$ have protective titers to fHbp and NadA and 79 to $87 \%$ for the OMV component, 1 month after the last dose.[74]Moreover 4CMenB immunogenicity is not affected by coadministration of other routine childhood vaccines. Thus, it can be administered in association with vaccines against diphtheria, tetanus, Haemophilus influenzae type b, hepatitis
B, measles, mumps, rubella and chickenpox.[12,48,75] The co-administration of $4 \mathrm{CMenB}$ with inactivated polio vaccine, pneumococcal conjugate vaccine and acellular pertussis vaccine caused a weakened immune response without suggesting clinically significant interference.[75] Simultaneous injection of 4CMenB with other meningococcal vaccines has not yet been analyzed.[76] This new vaccine therefore constitutes a major advance in the prevention of meningococcal disease. However its promising immunogenicity needs to be considered in the light of its safety profile.[48]

\section{3. $4 \mathrm{CMenB}$ tolerance}

Several clinical trials have evaluated the innocuousness and safety of the $4 \mathrm{CMenB}$ vaccine. In6,427 subjects $(4,843$ infants from 2 months, 1,503 adolescents and 81 adults), adverse effects were detected at a rate of up to $1 / 1000 \cdot[66,76]$

In one study involving $4 \mathrm{CMenB}$ vaccine versusa placebo, it was found that reactogenicity was lower among subjects who received verum.[65] The transient local reactions most frequently describedirrespective of agewere: pain, often described as severe, more frequent in the $4 \mathrm{CMenB}$ arm(from 79 to $93 \%$, compared to the placebo from 49 to $86 \%$ ), erythema (48 to $56 \%$ against 29 to $40 \%$ in the placebo group) and induration at the site of injection. The most common systemic reactions in infants and young children were: fever, irritability and sleepiness.[48,65,72,75] In clinical studies, fever appeared more often during 4CMenB administration than with other routine vaccines.[77] $5.2 \%$ of infants vaccinated with $4 \mathrm{CMenB}$ were taken to the pediatrician for febrility, against only $2.7 \%$ for a routine 
vaccine.[70] Fever rarely exceeded $39^{\circ} \mathrm{C}$ (40\% of infants showed fever $\geq 38.5^{\circ} \mathrm{C}$ after 1 and 2 doses of vaccine 4CMenB, $20 \%$ after the third dose, and less than $1 \%$ had a fever $\left.\geq 40^{\circ} \mathrm{C}\right)$. $[65,72]$ The febrile episodes, although usually mild and spontaneously resolved, caused anxiety among parents and health professionals, especially where they involved infants and possible febrile seizures were feared.[70,77,78] Prophylactic administration of phenacetincan be recommended to reduce theincidence and severity of fever.[77] This prophylaxis does not affect 4CMenB immunogenicity.[78,79] In adolescents and adults, frequently observed systemic reactions were discomfort (44 to $58 \%$ against 22 to $48 \%$ in the placebo) and headache (37$50 \%$ compared to $21-37 \%$ in the placebo).[74]The general safety profile of $4 \mathrm{CMenB}$ vaccine is similar to that ofMenZB, used in New Zealand to control a local epidemic.[65]This new vaccine appears to have an acceptable safety profile:no participant discontinued the trialbecause of troublesome adverse effects.[55] Local and systemic reactions are similar to those reported fromother vaccines.[6]Othermilder and less common adverse effects reportedin infants include changes in eating habits, unusual crying, vomiting, diarrhoea and rash.[66,75]

Some cases potentially attributable to $4 \mathrm{CMenB}$ vaccine have been reported: [48,72,75]

- 1 case of febrile seizures within 48 hours following vaccination (evolution was favorable)

- 2 cases of Kawasaki syndrome with a favorable evolution within 30 days of vaccination with $4 \mathrm{CMenB}$ in combination with other routine vaccines,

- 2 cases of idiopathic juvenile arthritis after vaccination
In clinical studieson co-administration of the new meningococcal vaccine with routine pediatric vaccines (vaccines against pneumococcal disease, diphtheria, tetanus, pertussis, hepatitis $\mathrm{B}$, polio and Haemophilus influenzae type b), an increased risk of systemic reactions was noted, especially fever. In fact, $32.2 \%$ of infants were reported to experience hyperthermia following administration of Bexsero $^{\circledR}$; and $65.3 \%$ when infants received Bexsero ${ }^{\circledR}$ simultaneously with routine vaccines.Thus, 4CMenB vaccine appears less reactogenic when administered alone,[48,75] and separate vaccinations are recommended whenever possible. When administration is simultaneous, it is preferable to inject in separate places.[80] Like all vaccines containing aluminum salts, 4CMenB may have additionnal adverse effects. According to some experimental studies, the aluminum used as an adjuvant in vaccines, could cause a number of disorders in humans, such as immunological disorders and neurological complications.[81,82]According to some reports, it may notably trigger a neuromuscular disease, macrophagicmyofasciitis, characterized by an infiltration of non-epithelioid histiocytic cells.[58]

\section{Place of $4 \mathrm{CMenB}$ in the immunization schedule}

\section{1. Current recommendations}

4CMenB vaccine was granted European authorization for active immunization against invasive meningococcal disease caused by Neisseria meningitidis group B. In view of the epidemiology of this pathogen, the authorization recommends the first injection from the age of 2 months, in order to optimize the vaccine's effectiveness.[12] After 1 to 2 doses administered at 1 month minimum intervals, some 
protection is already assumed.[55] However, one of the first strategies used in clinical trials, injecting the vaccine at 2, 4 and 6 months accompanied by a booster, may not be fully effective,particularly at 3-5 months. Thus, it is preferable to adopt an optimal immunization schedule at 2, 3, and 4 months accompanied by a booster dose between 12 and 23 months.[75] Adolescents, another population at risk, could also be vaccinated in the interests both of reducing nasopharyngeal carriage, and ofcreating collective immunity.Despite accreditation, this vaccine is not currentlyon the national immunization program in several countries including France, Spain, England, and Australia, for different reasons: either due to lack of efficacy data, or due to lack of profitability.[22,66,83-86] This failure to commit to the vaccine is a source of controversy and divided public opinion.[83]

\subsection{The cost of $4 \mathrm{CMenB}$ vaccination}

By definition, vaccines have the potential to reduceincidence ofdisease andtherebyto reduce direct and indirect costs.Today, the cost-effectivenessof a new drugisconsideredwhen adopting ofvaccination policies.[85]This ratio, also known ascost/performanceratio is calculatedin terms ofqualityadjusted life years(QALY) gained.[66,85] Severalvaccine strategieswere consideredand comparedtoabsence ofvaccination.Since irrespective ofprophylacticstrategy, the proportion ofprevented cases remains lower than $30 \%$.[66,87]

The absence ofconcrete proof ofherd immunity,the need for aprimary immunizationwith3dosesfollowed by a booster dose, the limited duration ofprotectionargue for relatively lowepidemiologicalimpact fromvaccination.The cost/effectivenessratio is high:ifeach dose ofvaccinecosts $€ 60$, and thedesiredcoverageis $80 \%$, cost/performanceratio variesfrom $€ 585,000$ to $€ 1,617,000 / Q A L Y$.[66]According to onestudy, a unit price of approximately€9fora routine childhoodvaccine strategywouldbe worthwhile.[87]

\subsection{CMenBvaccine acceptance}

The introduction of anew vaccinerequires carefulcommunicationfrompoliticaldecision-makers, health professionals,financingorganizations andthe media.[1]Public awarenessofdiseaseprevention though vaccine prophylaxishas been shown to lead to betteradoptionof immunization programs, which is essential to improveimmunization coverage.[66,70,77]Health educationis essential for theunderstandingof the new drugand particularlyfor itscommunity acceptance.[88]Parents shouldknow the benefits and risksof vaccinationbefore makingtheir decision.According toone study,the most importantfactor in determiningthe acceptance ofvaccinationisthe recommendation of theattending physician.[77]In fact,81.7\% of parents said they would agree tovaccination if their doctorrecommended it, $5.4 \%$ wereundecidedand $12.4 \%$ said the doctor's recommendationswould not affecttheir decision.[77]Among arguments whichcaninfluenceparents' choice, physicians cite the incidence, severity and unforeseen development of meningococcal disease.Moreover, according toanother study,alack of knowledge aboutdisease can lead topoor adherenceto thenew vaccine.[88]According toan Australianstudy of5,200families, while $39.9 \%$ felt positive aboutthis newdrug, $31.8 \%$ were concerned aboutpossible adverse effects. Furthermore, the financial aspectwas a factor 
in decisions: $74.1 \%$ of parents wishingto vaccinate theirchildrenwere prepared topay the price, however8.7\%were unwilling to payand $16.6 \%$ remained undecided.[77]

Physicians need to inform parents of the potential adverse effects to guide their decisions and to reassure them in case these side effects occur.The safety of drugs remains a difficult and worrying subject, particularly because of the potential risk of adverse effects not detected during clinical studies.[77]

\section{Vaccination limitations}

\subsection{Immunity loss}

According to current immunogenicity data, different vaccine schedules envisaged in the $4 \mathrm{CMenB}$ authorization require 3 doses of primary immunization to obtain sufficient protection. However, protection is not eternal: it decreases over time.[64,65] This immunological instability is generallyobserved with all other meningococcal vaccines, and especially with the first specific vaccines against serogroup B.[64,89,90]The decline seems clear from 2 months after the first dose. In fact, $69-81 \%$ of subjects receiving a single dose of vaccine still have seroprotective antibodies6 months later.[65] These observations illustrate a probable relatively rapid seroprotection decrease over time.Booster doses are essential to maintain a certain quantity of serologicantibodies.[74] 12 months after the first vaccination,followingbooster dose administration a strong anamnestic response was observed. Antibody titers, higher than those observed after primary vaccination reflect the establishment of immunological memory.[72,90]However, this phenomenon does not seem sufficient, and a certain quantity of bactericidal antibodies appears to be necessary for protection against meningococci.Therefore, if the quantityof circulating antibodies is not sufficient before infection, protective antibody synthesis will taketoo long to avoid bacterial invasion.[16]Thus, a booster dose 6 months after the second or third dose of $4 \mathrm{CMenB}$ restores the quantity of seroprotective antibodiesin 99 to $100 \%$ of subjects.[65] But after the booster dose, the seroprotectiontiters decrease again.[66,72,90] Studies found that this serologic decrease differs according tothe vaccine antigens of $4 \mathrm{CMenB}$, and is more pronounced with NHBA and PorA proteins.[72]

\section{2. Impact on nasopharyngeal carriage}

Although a vaccine is primarily designed for individual protection, its impact can also be measured in terms of an entire community. Indeed, if a vaccine is effective against asymptomatic carriage, then it reduces the probability of transmission, creating group immunity and indirectly protecting the unvaccinated.[91]The conjugate vaccine against meningococcal groupC, widely used in the UK, led to decreasednasopharynx bacterial colonization, correlated to decreasedmeningococcal incidence due to this serogroup.[91,92]Since, some antigens (fHbp and NadA) are also found in other serogroups,[93] this multi-antigenic vaccine may induce a protective effect against other serogroups expressing enough ofthese antigens.[73,93]Further studies are currently underway. If their findings confirm this first observation, $4 \mathrm{CMenB}$ vaccine would be particularly beneficial for young children and adolescents, whose rate of bacterial carriage is higher.[17,70] 


\subsection{Harmful effects of vaccination}

Meningococcus is a recombinant bacteria, inducing wide genetic variability.This pathogen is in fact able to incorporate into its chromosomes DNA captured from its environment, and frequently recombines DNA through the many repetitive sequences encoding components of the cell surface.[11,94]Similarly, the high frequency of an asymptomatic carriage of meningococcal strains in the commensal flora of the human nasopharynx can facilitate bacterial capsule switching, particularly in cases of simultaneous colonization of different meningococcal serogroups.[9]For example, in Canada and in Italy, cases of capsule switching between serogroups $\mathrm{B}$ and $\mathrm{C}$ have been observed.[95-97] The emergence of serogroup W135 connected with the pilgrims'return fromMecca, usually presenting a serogroup $\mathrm{C}$ clone, is another example.[96,98]These examples demonstrate the possibility of genetic exchange between endemic or epidemic strains. This diversity ultimately determines the virulence of the meningococcal strains, the ability of the host to defend itself and thus, indirectly, theimmunizationstrategies to adopt.[97]Under these circumstances, scientists fear that a mass vaccination program could cause a selection of strains targeted by this vaccine. Indeed, there may beprogressive emergence and the circulation of strains not covered by this vaccine, recalling past experience withpneumococcal vaccines.[9,70]So far, no capsular substitution has been demonstrated following the introduction of meningococcal vaccines.Nevertheless, post-implementation surveillance must be rigorously applied, in particular using the established typing method for meningococci,termedmultilocussequence typing (MLST). This method determines the molecular characterization of meningococcal strains, and identifies clones responsible forepidemics worldwide.[3,11]Such vigilance is aimed at rapidlyidentifying emergingstrains not covered by this vaccine, so that immunization policies can be adjusted for maximum effectiveness.[12] The best way to prevent an infectious disease is to eradicate theetiological agent, as done forsmallpox.In the case ofmeningococci, thisaim seems achievable since the number of virulent serogroups is limited, and the only reservoir is human.However, despite the severity of meningococcal disease, eradication of all meningococci is undesirable.[21]Indeed, the majority of meningococci, including serogroup B meningococci, form commensal bacterialflora. Thus, their disappearance fromthe human nasopharynx could havesevere consequences for natural immunity.[99]Human microbiome modification could increase the expression of pathogens of unknown virulence previously kept in check by the presence of meningococci.[21] The fight against the disease must therefore respect certain limits, primarily targeting encapsulated virulent meningitis.

The development of a universal vaccine against group B has proved a real clinical challenge, requiring decades of research. Finally, however, marketing authorizationis bringing hope ofcontrol of meningococcal epidemics.[10,38] A post-implementation surveillance plan is required to monitor the evolution of bacterial clones and toenhanceimmunization programs.[12,35] 
4CMenB was the first vaccinal prophylaxis proposed against Neisseria meningitidis serogroup B, but several vaccine candidate vaccines are currently under development. For example, Trumemba ${ }^{\circledR}$, a bivalent recombinant lipoprotein 2086 vaccine based on two fHBP, was recently licensed in United States; and a meningococcal pentavalent vaccine (ABCWY) is under study.[100]

Other preventive strategiesmay also be worth considering, such as the passive protection given to children by transfer of maternal antibodies during pregnancy.[10,12]

By helping to reduce the global burden of meningococcal disease, these therapeutics advances should contribute to the progress of modern medicine.

Conflict of interest:The authors declare that there is no conflict of interest pertaining to this work.

\section{Références}

1. Turner NM, York DG, Petousis-Harris HA. The use and misuse of media headlines: lessons from the MeNZBimmunisation campaign. NZMedJ 2009; 122:22-7.

2. Strelow VL, Vidal JE. Invasive meningococcal disease, ArqNeuropsiquiatr 2013;71:653-8.

3. Stephens DS. Biology and pathogenesis of the evolutionarily successful, obligate human bacterium Neisseria meningitidis. Vaccine2009; 27:B71-7.

4. Meningococcal vaccines: WHO position paper, Novembre2011.WklyEpidemiol Rec2011;86:521-39.

5. McIntyre PB,O'Brien KL,Greenwood B,Van De Beek D. Effect of vaccines on bacterial meningitis worldwide.Lancet2012;380:1703-11.
6. Roderick M, Finn A. Advances towards the prevention of meningococcal B disease: a multidimensional story. J Infect 2014;68:S76-82.

7. Whitney CG,Farley MM,Hadler J,Harrison LH, Bennett NM, Lynfield R, et al. Decline in invasive pneumococcal disease after the introduction of protein-polysaccharide conjugate vaccine. N Engl J Med.2003;348:1737-46.

8. Stephens DS, Greenwood B, Brandtzaeg P. Epidemic meningitis, meningococcaemia, and Neisseria meningitidis. Lancet 2007;369:2196-210.

9. Swartley JS, Marfin AA, Edupuganti S, Liu LJ, Cieslak P, Perkins B, et al. Capsule switching of Neisseria meningitidis. Proc Natl AcadSci USA 1997;94:271-76.

10. Yogev R, Tan T. Meningococcal disease: the advances and challenges of meningococcal disease prevention. Hum Vaccin 2011;7:828-37.

11. Racloz VN, Luiz SJ. The elusive meningococcal meningitis serogroup: a systematic review of serogroup B epidemiology. BMC Infect Dis 2010;10:175.

12. Kaaijk P, van der Ende A, Luytjes W. Routine vaccination against MenB: Considerations for implementation. Hum VaccinImmunother 2013;10:310-6.

13. Vipond C, Care R, Feavers IM. History of meningococcal vaccines and their serological correlates of protection. Vaccine 2012;30:B10-7.

14. Halperin SA,Bettinger JA,Greenwood B, Harrison LH, Jelfs J, Ladhani SN, et al. The changing and dynamic epidemiology of meningococcal disease.Vaccine2012;30:B26-36.

15. Djingarey MH, Barry R, Bonkoungou M, Tiendrebeogo S, Sebgo R, Kandolo D, et al. Effectively introducing a new 
meningococcal A conjugate vaccine in Africa: the Burkina Faso experience. Vaccine 2012;30:B40-5.

16. Cohn AC,MacNeil JR,Clark TA, Ortega-Sanchez IR, Briere EZ, Meissner HC, et al. Prevention and control of meningococcal disease: recommendations of the Advisory Committee on Immunization Practices (ACIP). MMWR Recomm Rep2013;62(RR-2):1-28.

17. Christensen H, May M, Bowen L, Trotter CL. Meningococcal carriage by age: a systematic review and meta-analysis. Lancet Infect Dis 2010;10:853-61.

18. INVS. Les infections invasives à méningocoque en France en 2011, Availablefrom : URL : http://www.invs.sante.fr/Dossiers-thematiques/Maladiesinfectieuses/Maladies-a-prevention-vaccinale/Infectionsinvasives-a-meningocoques/Donnees-epidemiologiques/Lesinfections-invasives-a-meningocoque-en-France-en-2011 [French]

19. MacLennan J,Kafatos G,Neal K,Andrews N, Cameron $\mathrm{JC}$, Roberts R, et al. Social behavior and meningococcal carriage in British teenagers. Emerg Infect Dis.2006;12:9507.

20. Pace D, Pollard AJ. Meningococcal disease: clinical presentation and sequelae. Vaccine 2012;30:B3-9.

21. Maiden MC, Frosch M. Can we, should we, eradicate the meningococcus? Vaccine 2012;30:B52-6.

22. Caron F, du Châtelet IP, Leroy JP, Ruckly C, Blanchard $\mathrm{M}$, Bohic $\mathrm{N}$, et al. From tailor-made to ready-to-wear meningococcal B vaccines: longitudinal study of a clonal meningococcal B outbreak Lancet Infect Dis 2011;11:45563.
23. Borrow R, Balmer P, Miller E. Meningococcal surrogates of protection - serum bactericidal antibody activity. Vaccine 2005;23:2222-7.

24. Holst J, Martin D, Arnold R, Huergo CC, Oster P, O'Hallahan J, et al. Properties and clinical performance of vaccines containing outer membrane vesicles from Neisseria meningitidis. Vaccine 2009;27:B3-12.

25. Finne J, Leinonen M, Makela PH. Antigenic similarities between brain components and bacteria causing meningitis. Implications for vaccine development and pathogenesis. Lancet 1983;2:355-7.

26. Sacchi CT, Whitney AM, Popovic T, Beall DS, Reeves MW, Plikaytis BD, et al. Diversity and prevalence of PorA types in Neisseria meningitidis serogroup B in the United States, 1992-1998. J Infect Dis 2000;182:1169-76.

27. FeaversIM , Pizza M. Meningococcal protein antigens and vaccines. Vaccine 2009;27:B42-50.

28. de Moraes JC, Perkins BA, Camargo MC, Hidalgo NT, Barbosa HA, Sacchi CT, et al. Protectiveefficacy of a serogroup B meningococcalvaccine in Sao Paulo, Brazil. Lancet 1992;340:1074-8.

29. Boslego J, Garcia J, Cruz C, Zollinger W, Brandt B, Ruiz $\mathrm{S}$, et al. Efficacy, safety, and immunogenicity of a meningococcal group B (15:P1.3) outer membrane protein vaccine in Iquique, Chile. Chilean National Committee for Meningococcal Disease. Vaccine 1995;13:821-9.

30. Sierra GV, Campa HC, Varcacel NM, Garcia IL, Izquierdo PL, Sotolongo PF, et al. Vaccine against group B Neisseria meningitidis: protection trial and mass vaccination results in Cuba. NIPH 1991;14:195-210.

31. Bjune G, Hoiby EA, Gronnesby JK, Arnesen O, Fredriksen JH, Halstensen A, et al. Effect of outer 
membrane vesicle vaccine against group B meningococcal disease in Norway. Lancet 1991;338:1093-6.

32. Oster P, Lennon D, O'Hallahan J, Mulholland K, Reid S, Martin D. MeNZB: a safe and highly immunogenic tailormade vaccine against the New Zealand Neisseria meningitidis serogroup B disease epidemic strain. Vaccine 2005;23:2191-6.

33. Oster P, O'Hallahan J, Aaberge I, Tilman S, Ypma E, Martin D.Immunogenicity and safety of a strain-specific MenB OMV vaccine delivered to under 5-year olds in New Zealand. Vaccine 2007;25:3075-9.

34. Caron F, Delbos V, Houivet E, Deghmane AE, Leroy JP, Hong E, et al.Evolution of immune response against Neisseria meningitidis B:14:P1.7,16 before and after the outer membrane vesicle vaccine MenBvac. Vaccine 2012;30:5059-62.

35. Holst J, Feiring B, Naess LM, Norheim G, Kristiansen P, Høiby EA, et al. The concept of "tailor-made", proteinbased, outer membrane vesicle vaccines against meningococcal disease. Vaccine 2005;23:2202-5.

36. Tappero JW, Lagos R, Ballesteros AM, Plikaytis B, Williams D, Dykes J, et al. Immunogenicity of 2 serogroup B outer-membrane protein meningococcal vaccines: a randomized controlled trial in Chile. JAMA 1999;281:15207.

37. Schubert-Unkmeir A,Christodoulides M. Genome-based bacterial vaccines: current state and future outlook. BioDrugs2013;27:419-30.

38. Caesar NM, Myers KA, Fan X. Neisseria meningitidis serogroup B vaccine development. MicrobPathog $2013 ; 57: 33-40$.
39. Nedelec J, Boucraut J, Garnier JM, Bernard D, Rougon G.Evidence for autoimmune antibodies directed against embryonic neural cell adhesion molecules (N-CAM) in patients with group B meningitis. J Neuroimmunol 1990;29:49-56

40. Bansal V,Kumar M,Dalela M, Brahmne HG, Singh H. Evaluation of synergistic effect of biodegradable polymeric nanoparticles and aluminum based adjuvant forimproving vaccine efficacy. Int J Pharm2014;471:377-84.

41. Bruge J,Bouveret-Le Cam N,DanveB,Rougon G, Schulz D.Clinical evaluation of a group $\mathrm{B}$ meningococcal $\mathrm{N}$ propionylated polysaccharide conjugate vaccine in adult, malevolunteers.Vaccine2004;22:1087-96.

42. Serruto D, Adu-Bobie J, Capecchi B, Rappuoli R, Pizza M, Masignani V. Biotechnology and vaccines: application of functional genomics to Neisseria meningitidis and other bacterial pathogens. J Biotechnol 2004;113:15-32.

43. Danzig L. Reverse vaccinology - in search of a genomederived meningococcal vaccine. Vaccine2006;24Supp12:112.

44. Rappuoli R. Reverse vaccinology, a genome-based approach to vaccine development. Vaccine $2001 ; 19: 2688$ 91.

45. Serruto D, Bottomley MJ, Ram S, Giuliani MM, Rappuoli R.The new multicomponent vaccine against meningococcal serogroup B, 4CMenB: immunological, functional and structural characterization of the antigens. Vaccine 2012;30:B87-97.

46. Kelly DF,Rappuoli R. Reverse vaccinology and vaccines for serogroup B Neisseria meningitidis. Adv Exp Med Biol.2005;568:217-23. 
47. Giuliani MM,Adu-Bobie J,Comanducci M, Aricò B, Savino S, Santini L, et al.A universal vaccine for serogroup B meningococcus. Proc Natl AcadSci USA2006;103:108349.

48. Vesikari T, Esposito S, Prymula R, Ypma E, Kohl I, Toneatto D, et al. Immunogenicity and safety of an investigational multicomponent, recombinant, meningococcal serogroup B vaccine (4CMenB) administered concomitantly with routine infant and child vaccinations: results of two randomised trials. Lancet 2013;381:825-35.

49. Murphy E, Andrew L, Lee KL, Dilts DA, Nunez L, Fink $\mathrm{PS}$, et al. Sequence diversity of the factor $\mathrm{H}$ binding protein vaccine candidate in epidemiologically relevant strains of serogroup B Neisseria meningitidis. J Infect Dis 2009;200:379-89.

50. Lucidarme J,Comanducci M,Findlow J, Gray SJ, Kaczmarski EB, Guiver M, et al. Characterization of fHbp, nhba (gna2132), nadA, porA, and sequence type in group B meningococcal caseisolates collected in England and Wales during January 2008 and potential coverage of an investigational group B meningococcal vaccine. ClinVaccineImmunol2010;17:919-29.

51. Comanducci M,Bambini S,Brunelli B,Adu-Bobie J, Aricò B, Capecchi B, et al.NadA, a novel vaccine candidate of Neisseria meningitidis. J Exp Med2002;195:1445-54.

52. Litt DJ,Savino S,Beddek A, Comanducci M, Sandiford C, Stevens J, et al. Putative vaccine antigens from Neisseria meningitidis recognized by serum antibodies of young children convalescing after meningococcal disease.J Infect Dis2004;190:1488-97.

53. Capecchi B,Adu-Bobie J,Di Marcello F, Ciucchi L, Masignani V, Taddei A, et al. Neisseria meningitidis NadA is a new invasin which promotes bacterial adhesion to and penetration into human epithelial cells. Mol Microbiol2005;55:687-98

54. Serruto D,Spadafina T,Ciucchi L, Lewis LA, Ram S, Tontini M, et al. Neisseria meningitidis GNA2132, a heparin-binding protein that induces protective immunity in humans.Proc Natl AcadSci U S A2010;107:3770-5.

55. Toneatto D, Ismaili S, Ypma E, Vienken K, Oster P, Dull P. The first use of an investigational multicomponent meningococcal serogroup B vaccine $(4 \mathrm{CMenB})$ in humans. Hum Vaccin 2011;7:646-53.

56. Giuliani MM,Biolchi A,Serruto D, Ferlicca F, Vienken $\mathrm{K}$, Oster $\mathrm{P}$, et al.Measuring antigen-specific bactericidal responses to a multicomponent vaccine against serogroup B meningococcus. Vaccine2010;28:5023-30.

57. FindlowJ, Borrow R,Snape M, Dawson T, Holland A, John TM, et al. Multicenter, Open-Label, Randomized Phase II Controlled Trial of an Investigational Recombinant Meningococcal Serogroup B Vaccine With and Without Outer Membrane Vesicles, Administered in Infancy. Clin Infect Dis 2010;51:1127-1137.

58. Gherardi RK, Coquet M, Cherin P, Authier FJ, Laforêt P, Bélec L, et al. Macrophagicmyofasciitis: an emerging entity. Lancet 1998;352:347-352.

59. Center for Disease Control and prevention. Meningococcal disease. Available from : URL : http://www.cdc.gov/meningococcal/outbreaks/vaccineserogroupb.html

60. FDA, Trumemba highlights of prescribing informations. Available from URL http://www.fda.gov/downloads/BiologicsBloodVaccines/Va ccines/ApprovedProducts/UCM421139.pdf 
61. Van Alphen L, van den Dobbelsteen G. Meningococcal

B vaccine development and evaluation of efficacy.Hum Vaccin 2008;4:158-61.

62. Goldschneider I, Gotschlich EC, Artenstein MS. Human immunity to the meningococcus. I. The role of humoral antibodies. J Exp Med 1969;129:1307-26.

63. Borrow R, Carlone GM, Rosenstein N, Blake M, Feavers I, Martin D, et al. Neisseria meningitidis group B correlates of protection and assay standardization - international meeting report Emory University, Atlanta, Georgia, United States, 16-17 March 2005. Vaccine 2006;24:5093-107.

64. Holst J, Feiring B, Fuglesang JE, Høiby EA, Nøkleby H, Aaberge IS, et al. Serum bactericidal activity correlates with the vaccine efficacy of outer membrane vesicle vaccines against Neisseria meningitidis serogroup B disease. Vaccine 2003;21:734-7.

65. Santolaya ME, O'Ryan ML, Valenzuela MT, Prado V, Vergara R, Muñoz A, et al. Immunogenicity and tolerability of a multicomponent meningococcal serogroup B (4CMenB) vaccine in healthy adolescents in Chile: a phase $2 b / 3$ randomised, observer-blind, placebo-controlled study. Lancet 2012;379:617-24.

66. Haut Conseil de la Santé Publique, vaccination contre les infections invasives à méningocoque $\mathrm{B}$, place du vaccin Bexsero® Availablefrom :

URL : http://www.hcsp.fr/explore.cgi/avisrapportsdomaine?clefr=3 86.[French]

67. Frasch CE, Borrow R, Donnelly J. Bactericidal antibody is the immunologic surrogate of protection against meningococcal disease. Vaccine 2009;27:B112-6.

68. Donnelly J, Medini D, Boccadifuoco G, Biolchi A, Ward J, Frasch C, et al. Qualitative and quantitative assessment of meningococcal antigens to evaluate the potential strain coverage of protein-based vaccines. ProcNatlAcadSci U S A. 2010;107:19490-5.

69. Vogel U,Taha MK,Vazquez JA, Findlow J, Claus H, Stefanelli P, et al.Predicted strain coverage of a meningococcal multicomponent vaccine $(4 \mathrm{CMenB})$ in Europe: a qualitative and quantitative assessment.Lancet Infect Dis2013;13:416-25.

70. Snape MD, Medini D, Halperin SA, DeTora L, Drori J, Moxon ER. The challenge of post-implementation surveillance for novel meningococcal vaccines.Vaccine 2012;30:B67-72.

71. Gill CJ. Novel assessment of a novel meningitis B vaccine.Lancet Infect Dis 2013;13:381-2.

72. Snape MD, Philip J, John TM, Robinson H, Kelly S, Gossger N, et al. Bactericidal Antibody Persistence 2 Years After Immunization With 2 Investigational Serogroup B Meningococcal Vaccines at 6, 8 and 12 Months and Immunogenicity of Preschool Booster Doses: A Follow-on Study to a Randomized Clinical Trial. Pediatr Infect Dis J $2013 ; 32: 1116-21$

73. Bettinger JA, Scheifele DW, Halperin SA, Vaudry W, Findlow J, Borrow R, et al. Diversity of Canadian meningococcal serogroup B isolates and estimated coverage by an investigational meningococcal serogroup B vaccine (4CMenB). Vaccine 2013;32:124-30.

74. Major M, Moss S, Gold R. From genes to vaccine: A breakthrough in the prevention of meningococcal group B disease. Paediatr Child Health 2011;16:e61-4

75. Gossger N,Snape MD,Yu LM,Finn A, Bona G, Esposito $\mathrm{S}$,et al.Immunogenicity and tolerability of recombinant serogroup B meningococcal vaccine administered with or 
without routine infant vaccinations according to different immunization schedules: a randomized controlled trial.JAMA2012;307:573-82.

76. Haut Conseil de la Santé Publique. Avis relatif à l'introduction du vaccin Bexsero ${ }^{\circledR}$ dans la campagne de vaccination contre le méningocoque $\mathrm{B}: 14: \mathrm{P} 1.7,16$ dans les départements de Seine Maritime et de la Somme. Available from :

URL : http://www.hcsp.fr/explore.cgi/avisrapportsdomaine?clefr=3 73 [French]

77. Marshall H, Clarke M, Sullivan T. Parental and community acceptance of the benefits and risks associated with meningococcal B vaccines. Vaccine 2014;32:338-44.

78. Prymula R, Siegrist CA, Chlibek R, Zemlickova H, Vackova M, Smetana J, et al. Effect of prophylactic paracetamol administration at time of vaccination on febrile reactions and antibody responses in children: two open-label, randomised controlled trials. Lancet 2009;374:1339-50.

79. Yalçin SS. Prophylactic paracetamol at the time of infant vaccination reduces the risk of fever, but also reduces antibody response. Evid Based Nurs 2010;13:76-7.

80. Carter NJ. Multicomponent meningococcal serogroup B vaccine (4CMenB; Bexsero $囚)$ : a review of its use in primary andbooster vaccination. BioDrugs 2013;27:263-74.

81. Kramer MF,Heath MD. Aluminium in allergen-specific subcutaneous immunotherapy- A German perspective. Vaccine2014;32:4140-8.

82. Tomljenovic L,Shaw CA. Aluminumvaccineadjuvants: are theysafe? Curr Med Chem.2011;18:2630-7.

83. Martinon-Torres F. Immunisation against meningococcus B: the case of Spain. Lancet2013;382:15523.
84. Holmes D. UK poisedtomake decisionon4CMenB vaccine. Lancet Infect Dis 2014;14:192-3.

85.Stephens DS,Ahmed R,Orenstein WA. Vaccines at what price?Vaccine2014;32:1029-30.

86. Moxon R, Snape MD. The price of prevention: what now for immunisation against meningococcus B. Lancet 2013;382:369-70.

87. Christensen H, Hickman M, Edmunds WJ, Trotter CL. Introducing vaccination against serogroup B meningococcal disease: an economic and mathematical modelling study of potential impact. Vaccine 2013;31:2638-46.

88. Wang B, Clarke M, Afzali HH, Marshall H. Community, parental and adolescent awareness and knowledge of meningococcal disease. Vaccine 2014;32:2042-9.

89. Vu DM,Welsch JA,Zuno-Mitchell P, Dela Cruz JV, Granoff DM. Antibody persistence 3 years after immunization of adolescents with quadrivalent meningococcal conjugate vaccine. J Infect Dis2006;193:8218.

90. Snape MD, Saroey P, John TM, Robinson H, Kelly S, Gossger $\mathrm{N}$, et al. Persistence of bactericidal antibodies following early infant vaccination with a serogroup B meningococcal vaccine and immunogenicity of a preschool booster dose. CMAJ 2013;185:E715-24.

91. Maiden MC,Spratt BG. Meningococcal conjugate vaccines: new opportunities and new challenges. Lancet1999;354:615-6.

92. Maiden MC,Stuart JM;UKMeningococcalCarraige Group. Carriage of serogroup $\mathrm{C}$ meningococci 1 year after meningococcal C conjugate polysaccharide vaccination.Lancet2002;359:1829-31. 
93. Pinto VB, Moran EE, Cruz F, Wang XM, Fridman A, Zollinger WD, et al. An experimental outer membrane vesicle vaccine from $N$. meningitidis serogroup B strains that induces serum bactericidal activity to multiple serogroups. Vaccine 2011;29:7752-8.

94. Bucci C,Lavitola A,Salvatore P, Del Giudice L, Massardo DR, Bruni CB, et al.Hypermutation in pathogenic bacteria: frequent phase variation in meningococci is a phenotypic trait of aspecializedmutator biotype. Mol Cell1999;3:435-45.

95. Kertesz DA,Coulthart MB,Ryan JA, Johnson WM, Ashton FE. Serogroup B, electrophoretic type 15 Neisseria meningitidis in Canada. J Infect Dis1998;177:1754-7.

96. Nair M. Protein conjugate polysaccharide vaccines: challenges in development and global implementation. Indian J Community Med 2012;37:79-82.

97. Stefanelli P, Fazio C, Neri A, Sofia T, Mastrantonio P.First report of capsule replacement among electrophoretic type 37 Neisseria meningitidis strains in Italy. J ClinMicrobiol 2003;41:5783-86.

98. Beddek AJ, Li MS, Kroll JS, Jordan TW, Martin DR.Evidence for capsule switching between carried and disease-causing Neisseria meningitidis strains. Infect Immun 2009;77:2989-94.

99. Heyderman RS, Davenport V, Williams NA. Mucosal immunity and optimizing protection with meningococcal serogroup B vaccines.Trends Microbiol 2006;14:120-4.

100. Marshall HS,Richmond PC,Nissen MD, Wouters A, Baber J, Jiang Q, et al. A phase 2 open-label safety and immunogenicity study of a meningococcal B bivalent rLP2086 vaccine in healthyadults. Vaccine2013;31):1569-

75. 